\title{
Impaired neutrophil function in intestinal lymphangiectasia
}

\author{
RP BOLTON, KL COTTER, MS LOSOWSKY \\ From the University Department of Medicine, St James's Hospital, Leeds
}

SUMMARY Impaired neutrophil chemotaxis and phagocytosis were shown in three patients with intestinal lymphangiectasia. Abnormalities in cell associated and serum derived activity occurred and possible mechanisms are suggested.

Intestinal lymphangiectasia is a disease characterised by dilated lymphatics, protein losing enteropathy, hypoalbuminaemia, and oedema; and patients with this disease lose albumin, immunoglobulins, and lymphocytes into the bowel. ${ }^{12}$ The condition may be primary, or secondary to underlying diseases-such as Crohn's disease, Whipple's disease, Behcet's syndrome, and cardiac failure. ${ }^{3}$ Patchy lymphatic dilatation is seen on small bowel biopsy specimens, and radiology may show characteristically oedematous mucosal folds with tiny filling defects caused by congested lacteals. The limb lymphatics are also commonly affected in primary intestinal lymphangiectasia, and lymphoedema may be severe.

Patients with intestinal lymphangiectasia have impaired cell mediated immunity, on skin testing and in vitro. ${ }^{1}$ This has been attributed to continuous loss of lymphocytes into the bowel lumen, ${ }^{4}$ but despite lymphopenia and hypogammaglobulinaemia, the consequences of impaired cellular immunity seem to be relatively few. Opportunistic infection is unusual, ${ }^{2}$ although severe cutaneous viral infections may occur. $^{56}$ These patients, however, may show prolonged poor health with recurrent, though relatively minor, bacterial infections of skin, respiratory and urinary tract, despite a generally satisfactory overall nutritional state achieved by dietary supplementation. ${ }^{78}$

Neutrophils have a major role in the body's defence against bacterial infection, but we are not aware of any previous reports of granulocyte function in intestinal lymphangiectasia. We report three patients with primary intestinal lymphangiectasia in whom standard in vitro tests of neutrophil function were abnormal.

\section{Accepted for publication 5 March 1986}

\section{Patients and methods}

The Table shows patient details. All three patients had a documented protein losing enteropathy an histological confirmation of lymphangiectasia on ${ }^{\text {? }}$ small bowel biopsy. Secondary disease was excludedeo by appropriate investigations. Two patients (cases $\stackrel{\circ}{\circ}^{\circ}$ and 2) showed hypoplastic lower limb lymphatics on lymphangiography. Case 1 had had severe disease throughout childhood and had gross lymphoedema He experienced recurrent cutaneous and respiratorya tract infections and had extensive cutaneous vira? warts. Case 2 also had severe disease with oedema anc? recurrent pleural effusions and, in addition, severê peripheral vascular disease.

All three patients were stable at the time of investigation, with no evidence of current bacteria? infection: they were receiving treatment with a low fan diet and dietary supplements, including vitamins ando medium chain triglycerides. Complement (C3 and C4) values were normal in all patients, and none hads evidence of spontaneous complement activation.

\section{ASSESSMENT OF NEUTROPHIL FUNCTION}

Neutrophils from patients and healthy controls were? separated from fresh heparinised blood by centrifu gation on a Ficol-metrizoate (Lymphoprep, Pharma cia) density gradient and sedimentation in 3\% dex $N$ tran. Contaminating erythrocytes were lysed by the् addition of $0.87 \%$ Tris buffered ammonium chloride $\sigma$ The remaining pellet of neutrophils was washed in medium (RPMI, Gibco) and resuspended at a fina: concentration of $2 \times 10^{6} / \mathrm{ml}$. Isolated neutrophils? were $95 \%$ pure and $98 \%$ viable, as based on trypan blue exclusion.

\section{CHEMOTAXIS}

This was measured using a modification of the 876 
Table Clinical and laboratory details of three patients with intestinal lymphangiectasia

\begin{tabular}{|c|c|c|c|c|c|c|c|c|}
\hline $\begin{array}{l}\text { Case } \\
\text { No }\end{array}$ & $\operatorname{Sex}$ & $\begin{array}{l}\text { Age } \\
\text { (years) }\end{array}$ & $\begin{array}{l}\text { Age at } \\
\text { diagnosis } \\
\text { (years) }\end{array}$ & $\begin{array}{l}\text { Albumin } \\
(g / l) \\
(n>36)\end{array}$ & $\begin{array}{l}\text { Total } \\
\text { immunoglobulin } \\
(g / l)(n>9 \cdot 5)\end{array}$ & $\begin{array}{l}\text { Lymphocyte } \\
\text { count } \times 10^{9} / l \\
(n>1.5)\end{array}$ & $\begin{array}{l}\text { Polymorphonuclear } \\
\text { count } \times 10^{9} / l \\
(n>2 \cdot 5)\end{array}$ & $\begin{array}{l}\text { Fibronectin } \\
(\mathrm{mg} / \mathrm{ml}) \\
(n>200 \mathrm{mg} / \mathrm{l})\end{array}$ \\
\hline $\begin{array}{l}1 \\
2 \\
3\end{array}$ & $\begin{array}{l}\mathbf{M} \\
\mathbf{M} \\
\mathbf{F}\end{array}$ & $\begin{array}{l}17 \\
49 \\
67\end{array}$ & $\begin{array}{r}3 \\
40 \\
66\end{array}$ & $\begin{array}{l}23 \\
28 \\
20\end{array}$ & $\begin{array}{l}4 \cdot 7 \\
8 \cdot 6 \\
5 \cdot 0\end{array}$ & $\begin{array}{l}0 \cdot 4 \\
1 \cdot 1 \\
1 \cdot 4\end{array}$ & $\begin{array}{l}2 \cdot 7 \\
7 \cdot 9 \\
4 \cdot 2\end{array}$ & $\begin{array}{l}125 \\
110 \\
145\end{array}$ \\
\hline
\end{tabular}

Boyden method. ${ }^{9}$ Serum activated by zymosan was used as the chemoattractant, and the distance migrated through the millipore filter (pore size $3 \mu \mathrm{m}$ ) was determined using the leading front method. Each test was performed in triplicate.

\section{PHAGOCYTOSIS}

This was assessed by incubating neutrophils with heat killed Candida albicans for 30 minutes at $37^{\circ} \mathrm{C}$. Each assay was performed in duplicate and after incubation the percentage of 200 cells ingesting Candida was counted on a smear slide stained with Giemsa. Neutrophil phagocytosis was taken as the mean percentage of cells ingesting Candida.

The normal ranges for chemotaxis and phagocytosis were taken as the mean ( $2 \mathrm{SD}$ ) of the values previously obtained in $\mathbf{4 0}$ healthy volunteers.

\section{FIBRONECTIN}

This was measured in citrated plasma by radial immunodiffusion (Serotec).

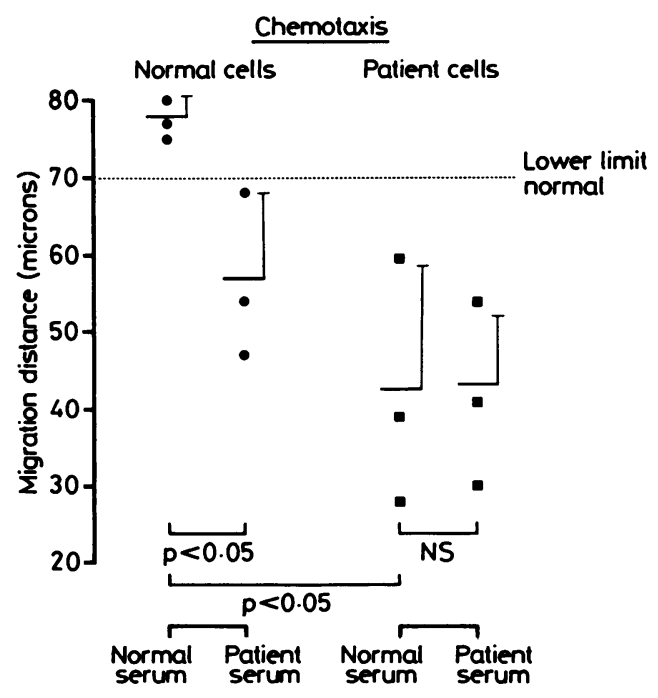

Fig. 1 Chemotaxis by neutrophils from patients with lymphangiectasia and from controls towards zymosan activated serum (patient and control).
Analysis was performed using the Mann-Whitney U test.

\section{Results}

Neutrophil morphology in the patients was normal with no excess of non-segmented, immature, or toxic forms.

\section{CHEMOTAXIS}

Random unstimulated neutrophil migration in the absence of serum was similar 22 (5) $\mu \mathrm{m}$ in both patients and controls.

Neutrophils from the patients with intestinal lymphangiectasia showed significantly reduced chemotaxis towards autologous 45 (12) $\mu \mathrm{m}$ and normal 42 (23) $\mu \mathrm{m}$ activated serum compared with that of control cells $(p<0.05)$ (Fig. 1). Normal neutrophils showed impaired chemotaxis towards patients'

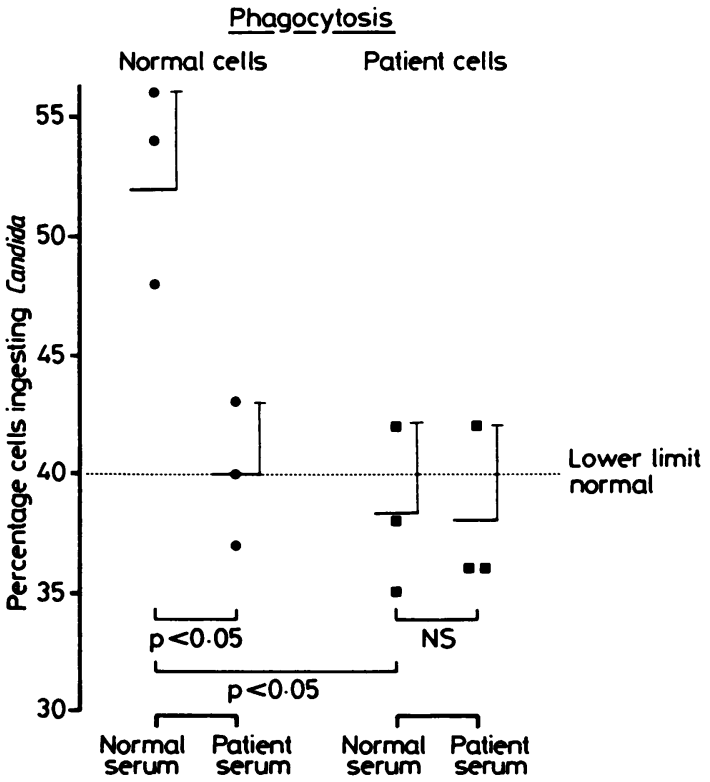

Fig. 2 Phagocytosis of heat killed Candida albicans by neutrophils from patients with lymphangiectasia and from controls in presence of patient and control serum. 
activated serum 57 (11) $\mu \mathrm{m}$ compared with that of normal serum $78(2) \mu \mathrm{m}(\mathrm{p}<0.05)$ (Fig. 1).

\section{PHAGOCYTOSIS}

Phagocytosis by neutrophils from the patients with intestinal lymphangiectasia was impaired in the presence of autologous $37(5) \%$ and normal serum 37.5 (5)\% compared with that of control cells $(p<0.05)$ (Fig. 2). Phagocytosis by normal neutrophils was impaired in the presence of patients' sera 40 (3)\% compared with that of normal serum $52(4) \%$ (p < 0.05) (Fig. 2).

\section{FIBRONECTIN}

These values were subnormal in all patients.

\section{Discussion}

The present study indicates that the neutrophil functions of chemotaxis and phagocytosis may be impaired in patients with intestinal lymphangiectasia, in terms of cellular and serum values. Reduced chemotaxis by patients' cells in the presence of normal serum indicates a defect within the cell, preventing normal migration (Fig.1). Chemotaxis is a complex process requiring recognition of a chemoattractant, orientation within its chemical gradient, and directed migration along that gradient. ${ }^{10}$ Specific receptors for various chemoattractants, including activated complement, ${ }^{11}$ bacterially derived peptides, ${ }^{12}$ and fibronectin ${ }^{13}$ have all been identified on the neutrophil membrane, and a change in receptor affinity, number, availability, or type might account for the present observations. Alternatively, the defect may lie further along the sequence of events required for normal chemotaxis; and abnormalities in microtubule formation ${ }^{14}$ and cellular adherence ${ }^{15}$ have occasionally been described in other conditions, leading to impaired migration.

Abnormal neutrophil mobility may occur in association with poor nutritional states in infants ${ }^{16}$ and children $^{17}$ but, although our patients were hypoalbuminaemic, their overall nutrition was satisfactory. Both impaired ${ }^{18}$ and enhanced ${ }^{19}$ mobility have been described in patients with active bacterial infection, but our patients had no evidence of current infection at the time of study. It has been suggested that immature neutrophils show reduced migration in vitro, ${ }^{20}$ but neutrophil morphology in our patients was normal with no excess of non-segmented forms.

In addition to the above abnormality in their neutrophils, our patients with intestinal lymphangiectasia also showed a reduced ability to generate normal chemoattractant activity in their serum, leading to impaired migration by normal cells (Fig. 1). Incubation of serum with zymosan produces activa- tion of complement via the alternative pathway, with the generation of highly chemoattractant com-으 plexes. ${ }^{10}$ Serum deficient in complement poorly promotes chemotaxis, ${ }^{2122}$ but this cannot be the explanation in our patients as complement values were? normal.

It has been suggested that fibronectin, a large $\frac{\overline{\bar{F}}}{\overline{\frac{\pi}{2}}}$ molecular weight protein found in both circulating $\underset{\varrho}{\mathbb{D}}$ and tissue bound forms, may play a part in chemotaxis, ${ }^{23}$ and the reduced concentrations of plasma ${ }_{-}$ fibronectin in our patients would support this theory. The origin of circulating fibronectin remains uncer- $\vec{\omega}$ tain, but as it is a globulin a lymphocyte origin has $\stackrel{\omega}{\circ}$ been suggested, ${ }^{24}$ and low concentrations might be $\overline{0}$ expected as part of the lymphocyte and immuno- $\dot{\omega}$ globulin depletion characteristic of intestinal lymphangiectasia.

Impaired serum chemoattractant activity may occur as a result of reduced endogenous stimu-응 lation, ${ }^{2526}$ or may be due to the presence of circu- lating inhibitors. ${ }^{27} 28$ Chemotactic factor directed $?$ inhibitors have been described in association witho impaired cell mediated immunity in sarcoidosis, ${ }^{29}$ की leprosy, ${ }^{30}$ and Hodgkin's disease, ${ }^{31}$ and inhibitors $\vec{\circ}$ cannot be excluded as the cause of serum defects in our patients.

One of our patients (case 2) developed the additional complication of hyposplenism, which has been reported elsewhere. ${ }^{32}$ Although defective neutrophil function has yet to be associated with medically acquired hyposplenism, reduced serum chemo- $\stackrel{\mathbb{Q}}{2}$ attractant activity has been described following sur- $\overrightarrow{\vec{B}}$ gical removal of the spleen. ${ }^{33}$ It has been proposed 3 that this results from reduced concentrations of circu- $\bar{F}$ lating tuftsin, an immunoglobulin derived tetra-? peptide produced in the spleen ${ }^{34}$ although this hypothesis has been disputed. ${ }^{35}$ We did not measure? tuftsin concentrations in our patients, but as neither 3 of our other patients showed any evidence of hypo-splenism, on the basis of blood film or pitted red cell $\frac{3}{3}$ count, ${ }^{36}$ tuftsin deficiency seems unlikely to have accounted for our findings and would not explain the $\supset$ additional cell based defect.

Reduced phagocytosis by neutrophils from our patients with intestinal lymphangiectasia, despite the $N$ presence of normal serum (Fig. 2), also indicates a cell $N$ based defect for this aspect of neutrophil function. N The sequences of neutrophil membrane activation $\omega$ leading to particle ingestion are complex and incompletely understood, and our findings do not indicate $\mathrm{a} C$ site for the observed defect.

Abnormalities of the cell cytoskeleton are known? to interfere with phagocytosis in the Chediak-Higashi $\frac{0}{0}$ syndrome, ${ }^{14}$ a rare inherited disease associated with $\frac{O}{\mathrm{D}}$

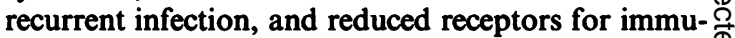
noglobulin on the neutrophil surface may predispose $\stackrel{\mathcal{Q}}{\circ}$ 
to infection in Felty's syndrome. ${ }^{37}$ Neutrophils from patients with iron deficiency show reversible defects in phagocytosis and intracellular killing, ${ }^{38}$ but iron studies in our patients were normal.

There was an additional abnormality in the sera of our patients: they failed to promote normal phagocytosis by control cells (Fig. 2). This defective opsonisation may reflect reduced concentrations of immunoglobulins or fibronectin, as both participate in the coating of particulate matter. ${ }^{39}$ Immunoglobulins, especially IgG, are important for the binding of coated particles to the neutrophil membrane by receptors specific for the Fc fragment, and synergy has been shown between IgG and complement (C3), enhancing phagocytosis. ${ }^{40}$ Fibronectin promotes bacterial attachment to the neutrophil, ${ }^{41}$ but its function in the actual process of phagocytosis has been questioned. ${ }^{40-42}$ The role of tuftsin in phagocytosis remains uncertain. .344

Although the full relevance of the observed abnormalities of neutrophil chemotaxis and phagocytosis in patients with intestinal lymphangiectasia requires further evaluation, it seems that impaired neutrophil function may lead to an increased susceptibility to infection in these patients.

\section{References}

${ }^{1}$ Strober W, Wochner RD, Carbone PP, Waldmann TA. Intestinal lymphangiectasia: a protein-losing enteropathy with hypogammaglobulinaemia, lymphocytopenia and impaired homograft rejection. J Clin Invest 1967;46:1643-56.

${ }^{2}$ Roberts SH, Douglas AP. Intestinal lymphangiectasia: the variability of presentation. A study of 5 cases. $Q J$ Med 1976;177: 39-48.

${ }^{3}$ Asakura H, Miura S, Morishita T, et al. Endoscopic and histopathological study on primary and secondary intestinal lymphangiectasia. Dig Dis Sci 1981;26:312-19.

${ }^{4}$ Weiden PL, Blaese RM, Strober W, Block JB, Waldmann TA. Impaired lymphocyte transformation in intestinal lymphangiectasia: evidence for at least two functionally distinct lymphocyte populations in man. J Clin Invest 1972;51:1319-25.

${ }^{5}$ Ward M, Leroux A, Small WP, Sircus W. Malignant lymphoma and extensive viral wart formation in a patient with intestinal lymphangiectasia and lymphocyte depletion. Postgrad Med $J$ 1977;53:753-7.

${ }^{6}$ Ross IN, Chesner I, Thompson RA, Parker RG, Asquith P. Cutaneous viral infection as a presentation of intestinal lymphangiectasia. Br J Dermatol 1982;107:357-64.

${ }^{7}$ Holt PR. Dietary treatment of protein loss in intestinal lymphangiectasia. Paediatrics 1964;34:629-35.

8 Jeffries GH, Chapman A, Sleisenger MH. Low-fat diet in intestinal lymphangiectasia: its effect on albumin metabolism. New Engl J Med 1964;270:761-6.

${ }^{9}$ Frei PC, Balsero M, Ochsner M. Chemotaxis of human polymorphonuclears in vitro. II. Technical study. J Immunol Methods 1974;5:373-86.

${ }^{10}$ Zigmond SH. Chemotaxis by polymorphonuclear leucocytes. J Cell Biol 1978;77:269-87.

${ }^{11}$ Chenoweth DE, Hugh TE. Demonstration of specific C5a receptor on intact human neutrophils. Proc Natl Acad Sci USA 1978;75:3943-7.

12 Wilkinson PC. Leucocyte locomotion and chemotaxis: effects of bacteria and viruses. Rev Infect Dis 1980;2:293-318.
${ }^{13}$ Hoffstein ST, Weissman G, Pearlstein E. Fibronectin is a component of the surface coat of human neutrophils. J Cell Sci 1981;50:315-27.

${ }^{14}$ Boxer LA, Albertini DF, Baehner RL, Oliver JM. Impaired microtubule assembly and PMNL function in the Chediak-Higashi syndrome, correctable by ascorbic acid. Br J Haematol 1979;43:207-13.

${ }^{15}$ Christou NV, Meakins JL. Neutrophil function in anergic surgical patients: neutrophil adherence and chemotaxis. Ann Surg 1979;190:557-64.

${ }^{16}$ Anderson DC, Krishna GS, Hughes BJ, et al. Impaired PML motility in malnourished infants: relationship to functional abnormalities of cell adherence. J Lab Clin Med 1983;101: 881-94.

${ }^{17}$ Schopfer K, Douglas SD. Neutrophil function in children with Kwashiorkor. J Lab Clin Med 1976;88:450-61.

${ }^{18}$ Rebora A, Dallegri F, Patrone F. Neutrophil dysfunction and repeated infections: influence of levamisole and ascorbic acid. Br J Dermatol 1980;102:49-55.

${ }^{19}$ Solber CO, Hellum KB. Neutrophil granulocyte dysfunction in bacterial infections. Lancet 1972;ii:727-31.

${ }^{20}$ Maderazo EG, Woronick CL. Quantitating functional capacity of mature and immature (non-segmented) neutrophils. J Infect Dis 1983;147:781-5.

${ }^{21}$ Alper CA, Stossel TP, Rosen FS. Genetic defects affecting complement and host resistance to infection. In: Belanti J, Dayton DH, eds. The phagocyte cell in host resistance. New York: Raven Press, 1975:127-41.

22 Wyke RJ, Yousif-Kadaru AGM, Rajkovic IA, Eddleston AL, Williams R. Serum stimulating activity and polymorphonuclear leucocyte movement in patients with fulminant hepatic failure. Clin Exp Immunol 1982;50:442-9.

${ }^{23}$ Deitch EA, Gelder F, McDonald JC. The relationship between CIG depletion and peripheral neutrophil function in rabbits and man. J Trauma 1982;22:469-75.

${ }^{24}$ Pearlstein E, Gold LI, Garcia-Pardo A. Fibronectin: a review of its structure and biological activity. Mol Cell Biochem 1980;29: 103-28.

${ }^{25}$ Elmgreen J. Subnormal activation of phagocytes by complement in chronic inflammatory bowel disease? Neutrophil chemotaxis to complement split product $C_{5}$ A. Gut 1984;25:737-42.

${ }^{26}$ Yousif-Kadaru AGM, Rajkovic IA, Wyke RJ, Williams R. Defects in serum attractant activity in different types of chronic liver disease. Gut 1984;25:79-84.

${ }^{27}$ Rhodes JM, Potter BJ, Brown DJC, Jewell DP. Serum inhibitors of leucocyte chemotaxis in Crohn's disease and ulcerative colitis. Gastroenterology 1982;82:1327-34.

${ }^{28}$ Van Epps DE, Strickland RG, Williams RC. Inhibitors of leucocyte chemotaxis in alcoholic liver disease. Am J Med 1978; 59:200-7.

${ }^{29}$ Maderazo EG, Ward PA, Woronick CL, Kubik J, DeGraff AC. Leukotactic dysfunction in sarcoidosis. Ann Intern Med 1976;84:414-19.

${ }^{30}$ Ward PA, Goralnick SG, Bullock WE. Defective leukotaxis in patients with lepromatous leprosy. J Lab Clin Med 1976;87:1025-32.

${ }^{31}$ Ward PA, Berenberg JL. Defective regulation of inflammatory mediators in Hodgkin's Disease: supernormal levels of chemotactic-factor inactivator. New Engl J Med 1974; 290:76-80.

${ }^{32}$ Foster PN, Bullen AW, Robertson DAF, Chalmers DM, Losowsky MS. Development of impaired splenic function in intestinal lymphangiectasia. Gut 1985;26:861-4.

${ }^{33}$ Foster PN, Boiton RP, Cotter KL, Losowsky MS. Defective activation of neutrophils after splenectomy. J Clin Pathol 1985;38:1175-8.

${ }^{34}$ Spirer Z, Zakuth V, Diamant S, et al. Decreased tuftsin concentrations in patients who have undergone splenectomy. $\mathrm{Br}$ Med J 1977;ii:1574-6.

${ }^{35}$ Goetzl EJ. Neutrophil chemotactic inhibitors. Ann NY Acad Sci 1975;256:210-21. 
${ }^{36}$ Corazza GR, Bullen AW, Hall R, Robinson PJ, Losowsky MS. Simple method of assessing splenic function in coeliac disease. Clin Sci 1981;60:109-13.

${ }^{37}$ Breedveld FC, Lafeber GJM, De Vries E, Leyh PCJ, Daha MR, Cats A. Fc receptors on granulocytes from patients with rheumatoid arthritis and Felty's syndrome. Clin Exp Immunol 1984;55:677-83.

${ }^{38}$ Moore LL, Humbert JR. Neutrophil bacteriacidal dysfunction towards oxidant radical-sensitive micro-organisms during experimental iron deficiency. Pediatr Res 1984;18:684-9.

${ }^{39}$ Van De Water L, Destree AT, Hynes RO. Fibronectin binds to some bacteria but does not promote their uptake by phagocytic cells. Science 1983;220:201-4.

${ }^{40}$ Hakanson L, Venge P. Kinetic studies of neutrophil phagocytosis. $\mathrm{V}$. Studies on the cooperation between $\mathrm{Fc}$ and $\mathrm{C}_{3} \mathrm{~b}$ receptors. $J$ Immunol 1982;47:687-94.

${ }^{41}$ Proctor RA, Prendergast E, Mosher D. Fibronectin mediates attachment of $\mathrm{S}$ aureus to human neutrophils. Bloo 1982;59:681-6.

${ }^{42}$ Czop JK, Austen KF. Augmentation of phagocytosis by a specific fibronectin fragment that links particulate activators to the fibronectin adherence receptor of human monocytes. $J$ Immun of 1982;129:2678-81.

${ }^{43}$ Fridkin M, Stabinsky Y, Zakuth V, Spirer Z. Tuftsin and some analogues: synthesis and interaction with human polyo

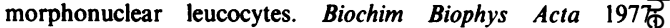
496:203-11.

${ }^{44}$ Cooper MR, De Chatelet LR, Shirley PS, Cooper RM. Doळ్ tuftsin alter phagocytosis by human polymorphonuclear neutrophils? Inflammation 1982;6:103-12.

Requests for reprints to: Dr RP Bolton, Universit Department of Medicine, St James's Hospital, Leed LS9 7TF, England. 